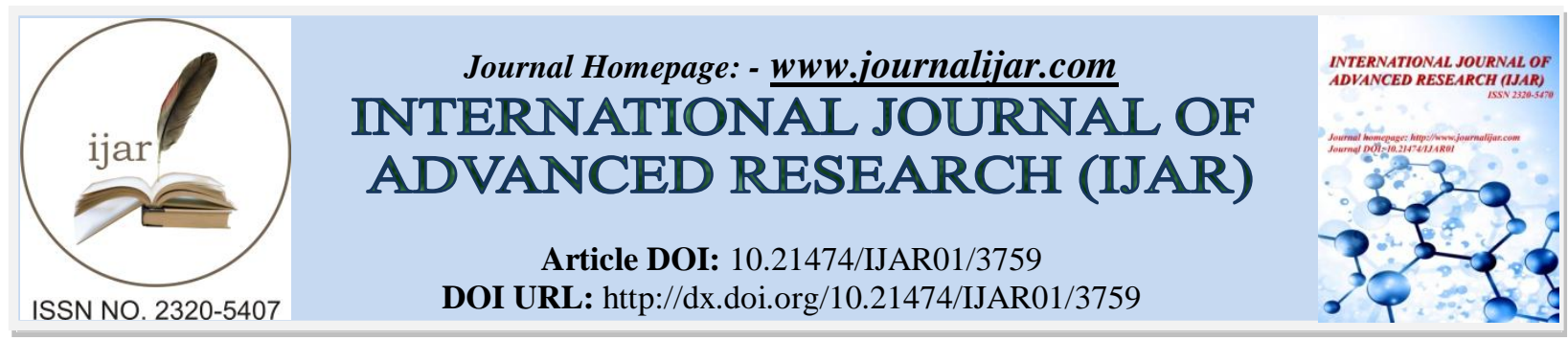

RESEARCH ARTICLE

\title{
GROUNDWATER MODELING OF SHALLOW AQUIFER IN LAYLAN SUB-BASIN / NE IRAQ.
}

Omer S. AL-Tamimi ${ }^{1}$ and Jailan A. AL-Mukhtar ${ }^{2}$.

1. Head of Environmental Research unit,College of Science, University of Kirkuk, Kirkuk, Iraq.

2. Master Student at Dept. of Geology, College of Science, University of Mosul.

\section{Manuscript Info}

Manuscript History

Received: 16 January 2017

Final Accepted: 14 February 2017

Published: March 2017

Key words:-

Ground water,Modeling,Laylansubbasin,Iraq.

\begin{abstract}
A Mathematical model has been done for the study area (Laylan subbasin) in Kirkuk / NE of Iraq byModflow pro software. To make a simulation for the shallow aquifer to predict a clear future imagination about the hydraulic head. The aquifer receives $23.29 \mathrm{~mm}$ in January, $49.44 \mathrm{~mm}$ February, $25.17 \mathrm{~mm}$ in March. According to such conditions with no sinks, the model was run, after converting the water surplus to the used unit in the model $\mathrm{m} /$ day..The model output in the monthly flow map depends on the variation of the above package (groundwater recharge).The calculated head values for each step are noticed showing slight differences in head values.Another simulation was run with sinks for one year divided also to 12 stress period The calculated hydraulic head after 1-year simulation with thewithdrawal of groundwater estimated by $-432 \mathrm{~m}^{3}$ / day of 70 wells, theSmall difference in hydraulic heads was noticed when comparing the readings of both simulations (with or without pumping). The model was run after reloading the mentioned stresses, and with increasing 10 wells yearly (as an assumption), the result shows that there will be a decrease in the southern and northern parts toward the center of the modeled area.
\end{abstract}

Copy Right, IJAR, 2017,. All rights reserved.

\section{Introduction:-}

Groundwater Modeling is an efficient tool for groundwater management (Harbaugh AW, et al., 2000). Models are a simplification of reality to investigate certain phenomena or to predict future behavior of groundwater. Despite their efficiency, models can be complicated and produce wrong results if they are not properly designed and interpreted. Regardless of the type of model being used, similar sequences should be followed in modeling. If the conceptual model is not properly designed, all modeling processes will be a waste of time and effort. To build a proper conceptual model, hydrogeological data should be sufficient and reliable. Calibration and verification are the last steps in modeling before writing the final model report (Todd DK, and Mays LW.,2005). Groundwater management and policy decisions must be based on knowledge of the past and present behavior of the groundwater system, the likely response to future changes and the understanding of the uncertainty in those responses(Sinclair Knight Merz,2012).The purpose of modeling can vary widely, and the approach used may depend on site-specific needs, current understanding of the hydrogeologic system, availability of input data, and expectation and use of the model results. Models are typically used to evaluate ground water movement, flow direction, velocity, and discharge ratesbeside:

-Evaluate the interaction between hydrogeologic systems.

-Interpolate between known measurement points. 
-Identify data gaps during site characterization.

-Aid in the development and management of groundwater supply systems.

Models are not a substitute for field investigations but should be used as supplementary tools. Results depend on the quality and quantity of the field data available to define input parameters and boundary conditions (Wang ,H.F., and Anderson,M.P., 1982). The results should always be evaluated in context with the fundamental assumptions of the model and the adequacy of the input data. A general rule, it is prudent to continually question the results of modeling and the potential consequences of decisions based on misleading results, and consider what can be done to verify the results (U.S. EPA., 1996c).

\section{Location of Study area:-}

The study area (Laylan) located in the northeastern part of Iraq, it is a sub-basin belongs to Kirkuk province. Laylan is approximately $26 \mathrm{Km}$ to the southeast of the governorate capital, Kirkuk. Geographically, the area of study lies in

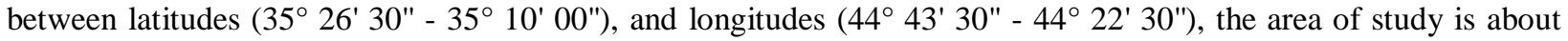
$256 \mathrm{~km}^{2}$. These places belong Kirkuk province. Geologically, structural boundaries for the study area from east and northeast by Kirkuk anticline, while in the west and southwest by Jambur Mountains (Anticline), and it is bounded by hydrological natural boundaries from north and northwest by ephemeral stream (intermittent stream named Shireen valley), while in the south and southwest by ephemeral stream named(Qarqacha valley) (Figure 1).
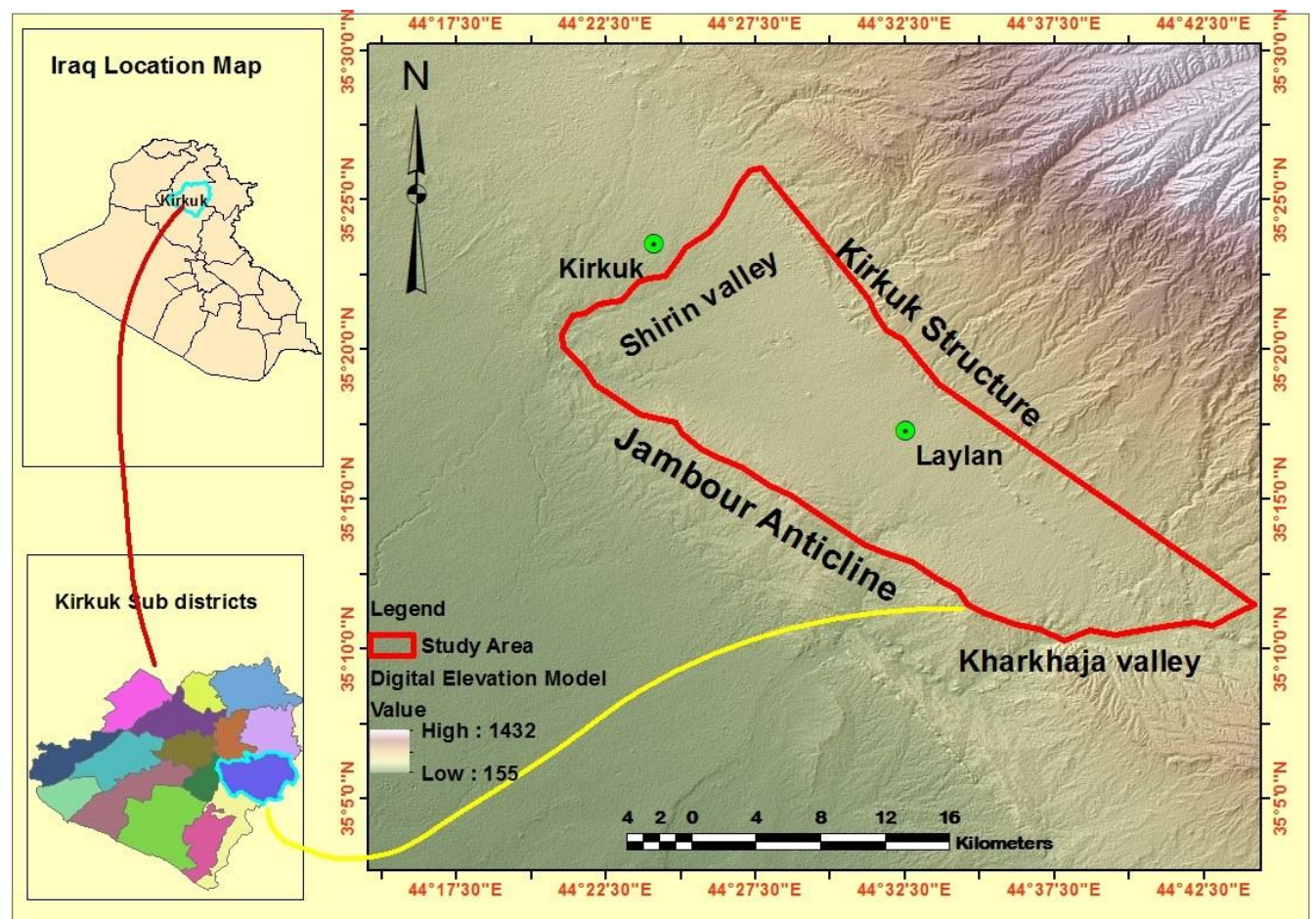

Figure (1):- Location of the study area.

\section{General Setting of Tectonic, Geology, and Structure of the Study Area:-}

Lailan sub-basin contains Mukdadyia (L. Pliocene) andBai-Hassan (U. Pliocene) Formations with a cover of Pleistocene andHolocene Quaternary deposits.Groundwater exists abundantly in sand and gravel layers of Quaternaryand Bai Hassan Formation. Lailan located within unstable shelf in the deepest part of the FoothillZone, which called Hemrin-Makhul Subzone. The subzone was thedepocentre of the Neogene molasses but has been a subsiding unitthroughout the Mesozoic and Tertiary (Jassim and Goff,2006),AL-Mamuri (2005).

\section{Methodology:-}

The research in done by using the hydrogeological field data to build aproper model for the study area (Laylansubbasin) through the following steps: 


\section{Grid Design:-}

The dimensions of the model should be selected during the formulation of the conceptual model. To minimize a variety of sources of numerical errors the model grid should be designed using the finest mesh spacing and time steps. In designing the grid, the length to width ratio (or aspect ratio) of cells or elements should be kept as close to one as possible. Long linear cells or elements can lead to numerical instabilities or errors and should be avoided, particularly if the aspect ratio is greater than about (Jacques W. Delleur,2006).The modeledarea was $256 \mathrm{~km}^{2}$, this area was divided into355 cells, the dimension of each cell is $(750 \mathrm{~m} * 1000 \mathrm{~m})$, all these cells are active.

\section{Boundary \& Initial Conditions:-}

To obtain a unique solution of a partial differential equation corresponding to a given physical process, additional information about the physical state of the process is required. This information is supplied by boundary and initial conditions. The boundary conditions include the geometry of the boundary, for groundwater model applications, the initial conditions are simply the values of the dependent variable specified everywhere inside the boundary at the start of the simulation. Normally, the initial conditions are specified to be a steady-state solution. It should be recognized that heads will change during the transient simulation, not only in response to the new pumping stress but also due to the initial conditions. Boundary conditions have great influence on the computation of flow velocities and heads within the modeled area.The boundary conditions which are used in the modeled area, specified head positive values (+1) in the I Bound array defines active cells when expressing the domain inside.

\section{Initial Hydraulic heads:-}

MODFLOW requires initial hydraulic heads at the beginning of a flow simulation. For steady state simulation, the initial heads are used as starting values. Actual, confidential head values were derived from the hydrogeologic data bank of groundwater commission. GIS, the3D spatial analyst is used to create initial isopotential lines. The isopotential lines of the aquifer, the same values were loaded into the model as initial hydraulic heads.

\section{Aquifer Material Properties:-}

The model needs more additional properties such as top and bottom of the aquifer beside transmissivity...Etc, the values were loaded into the model.Flow packages represented by recharge (L/T) which means length unit /time unit, positive values, and wells $\left(\mathrm{L}^{3} / \mathrm{T}\right)$, negative values, will add to the model during simulation of the Transientmodel. Recharge is defined by assigning the data to each vertical column of cells. The model assumes that a well penetrates the full thickness of the cell. To calculate heads in each cell in finite difference grid, GMS prepares one finite difference equation for each cell. SIP (strongly implicit procedure) package is used to solve the system of afinite difference equation.

\section{Results and Discussion:- \\ Steady State Simulation:-}

Flow in such simulation means the volume passing a given point per unit of time remains constant. An initial steadystate condition is required for time-dependent modeling of groundwater flow. After loading data and after running the model, hydraulic heads are the primary results of themodel as a steady state simulation will appear as in (Figure 2 ). 


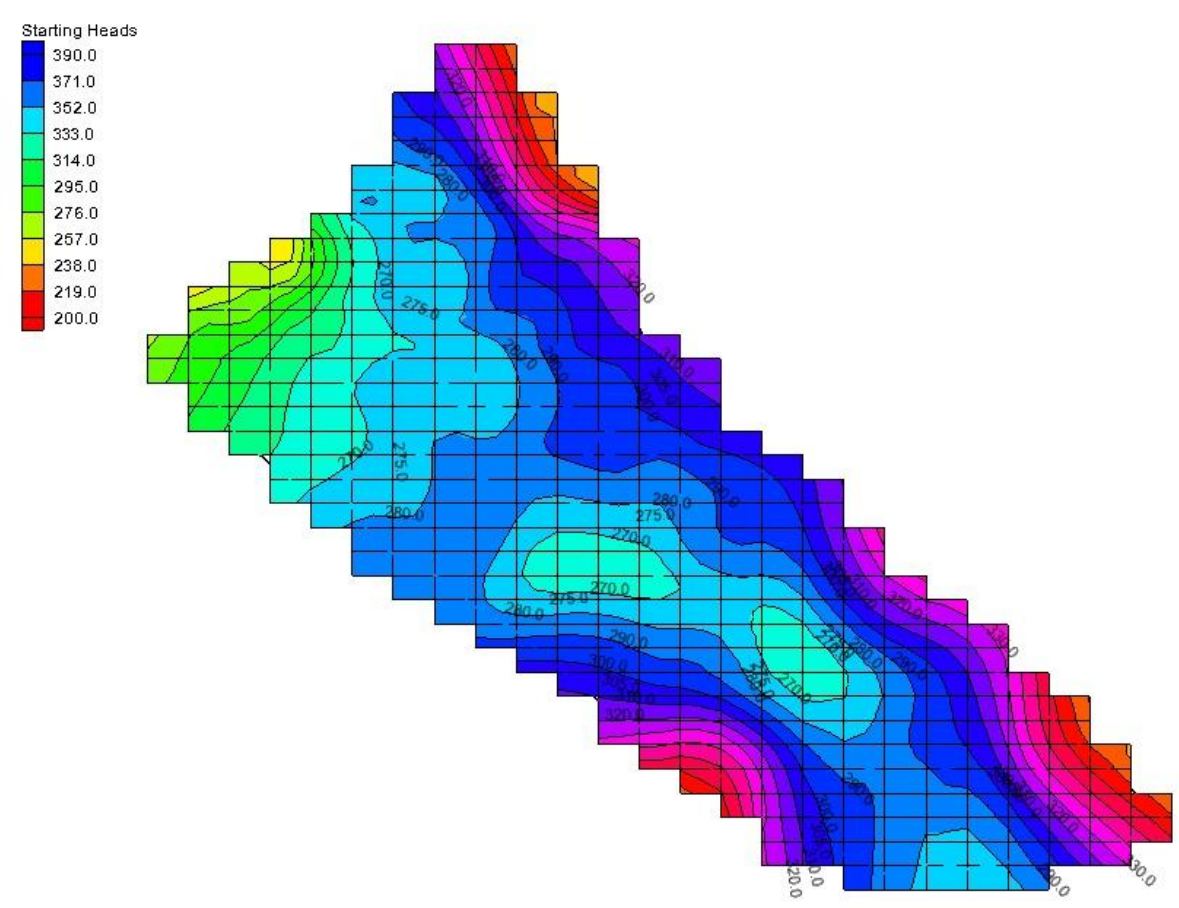

Model Calibrations:-

Figure (2):-Steady State Simulation

Calibration is the process of adjusting model inputs to achieve the desired degree of correspondence between the model simulations and the natural groundwater flow system(Christoph Wels,2012). In other words, calibration methods are used until the solution matches the known (usually hydraulic heads).For this model, calibration is made for inputs to reach the matching between inputs and model simulation. Model calibration should include comparisons between model-simulated conditions and field conditions for the following data.

\section{Transient Simulation:-}

Transient simulation involves the change in hydraulic head with time. These simulations are needed to narrow the range of variability in model input data since there are numerous choices of model input data values which may result in similar steady-state simulations.

The first attempt in thetransient simulation is made with an assumption without withdrawal water from the aquifer. The flow recharge package is the most important factor included in this simulation due to thedifference in climatological factors, groundwater recharge as a source is an influenced factor during three months in a year according to the calculations of water surplus. The aquifer receives $23.29 \mathrm{~mm}$ in January, $49.44 \mathrm{~mm}$ February, $25.17 \mathrm{~mm}$ in March. According to such conditions with no sinks, the model was run, after converting the water surplus to the used unit in the model $\mathrm{m} /$ day.

\section{Time stepping in transient simulation:-}

The time for one-year simulation without sinks (wells) is divided to 12 stress periods, each stress period represents a month, while the period length of each stress period are divided into days,so the total time steps equal to 12 months, while the total simulation time equals to $3.65 \mathrm{E}+2$ days. The model output in the monthly flow map depends on the variation of the above package (groundwater recharge). The calculated head values for each step are noticed showing slight differences in head values.

Another simulation was run with sinks for one year divided also to 12 stress period The calculated hydraulic head after 1 year simulation with withdrawal of groundwater estimated by $-432 \mathrm{~m}^{3} /$ day of 70 wells, Small difference in hydraulic heads was noticed when comparing the readings of both simulations (with or without pumping) (Figure 3). 


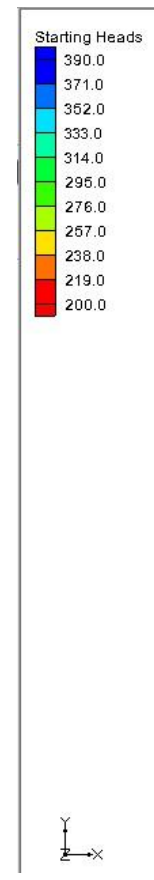

Predictive simulation:-

A model can be used to predict future groundwater flow conditions, such simulation estimates the hydraulic response of an aquifer, and also it can predict the pumping rate needed to monitor the hydraulic heads.

A pumping strategy (groundwater management) is a set of spatially and possibly temporary distributed rates of extracting water from theaquifer.

To predict the simulation for 5 years, the stress period were divided into20 stress periods, each one-year simulation divides into 2-period lengths, 1 for thewet period represented by 90days while the another one for thedry period represented by 270 days.

For utilization of 70 wells for agricultural purpose, wells flow package represented by estimated withdrawal of (432) $\mathrm{m}^{3}$ /day during the dry period and $(-216) \mathrm{m}^{3} /$ day during wet season, recharge flow package represented by $(0.00108) \mathrm{m} /$ day during the wet season and $(0)$ during the dry season. The model was run after reloading the mentioned stresses, and with increasing 10 wells yearly ( as an assumption ), the result shows that there will be a decrease in the southern and northern parts toward the center of the modeled area ( figure 4) 


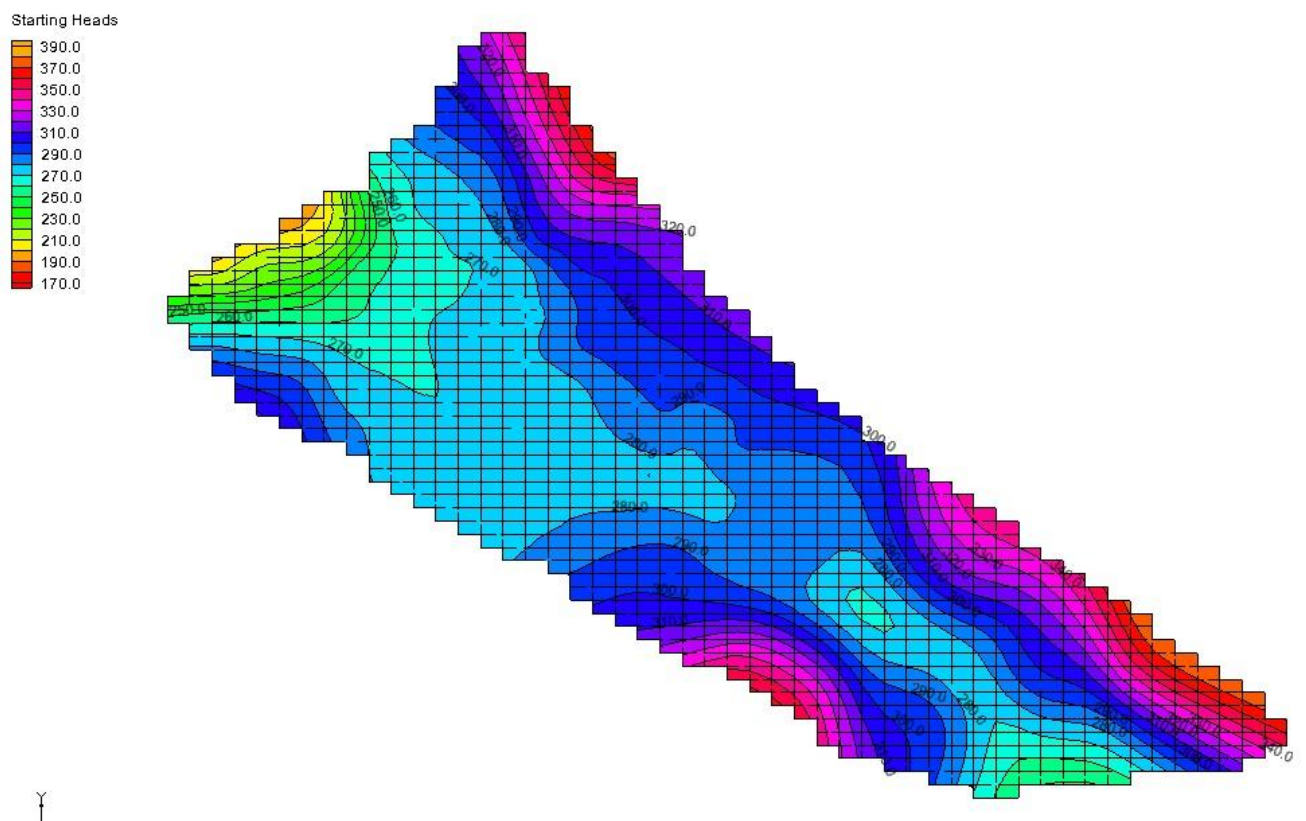

figure (4):- 5 Years later Simulation

\section{References:-}

1. AL-Mamuri, N. M. L., 2005: Optimum Management of Surface \&Subsurface Water of AL-AdhaimBasin, Ph. D., Thesis, College ofEngineering, Uni. of Baghdad, 158 p.

2. Christoph Wels,2012,Guidelines for Groundwater Modelling to Assess Impacts of Proposed Natural Resource Development ActivitiesBritish Columbia Ministry of Environment Water Protection \& Sustainability Branch.

3. Harbaugh, A.W., 2005. MODFLOW-2005, the U.S. Geological Survey's Modular Ground-Water Flow Model e The Groundwater Flow Process.Techniques andMethods 6eA16. U.S. Geological Survey, Reston, Virginia.

4. Jacques W. Delleur 2006, The Handbook of Groundwater Engineering by CRC Press ISBN 9780849343162 CAT\# 4316.

5. Jassim, S.Z. and Goff, J.C., 2006: Geology of Iraq, First edition, CzechRepublic, Isban, 341p.

6. Todd DK, Mays LW.,2005, Groundwater hydrology. 3rd ed. NY: John Wiley and Sons, Inc.

7. Sinclair Knight Merz and National Centre for Groundwater Research and Training Waterlines Report Series, 2012, Australian groundwater modeling guidelines, Published by the National Water Commission: No. 82, June 2012.

8. U.S. EPA. 1996c, Assessment, and Application to Environmental Mixtures. Office of Research and Development, Washington, DC. EPA/600/P-96/001A.

9. Wang,H.F.,Anderson,M.P. 1982, Introduction to Ground water Modeling: Finite Difference and Finite Element Methods,Academic Press INC.237 P. 